\title{
Hypoglycemia, Hepatic Dysfunction, Muscle Weakness, Cardiomyopathy, Free Carnitine Deficiency and Long-Chain Acylcarnitine Excess Responsive to Medium Chain Triglyceride Diet
}

\author{
ALLEN M. GLASGOW, ${ }^{(46)}$ ANDREW G. ENGEL, DENNIS M. BIER, LOWELL W. PERRY, \\ MARY DICKIE, JANE TODARO, BARBARA I. BROWN, AND MERTON F. UTTER \\ Departments of Endocrinology and Metabolism [A.M.G.], Gastroenterology [J.T.], Cardiology [L.W.P.] and Dietary \\ [M.B.], Children's Hospital National Medical Center, Washington, D.C.; Department of Neurology, and the \\ Neuromuscular Research Laboratory [A.G.E.], Mayo Clinic and Mayo Foundation, Rochester, Minnesota USA; \\ Departments of Medicine and Pediatrics [D.M.B.] and Biochemistry [B.I.B.], Washington University, School of \\ Medicine, St. Louis, Missouri, USA; and Department of Biochemistry [M.F.U.], Case Western Reserve, \\ Cleveland, Ohio, USA
}

\section{Summary}

Fraternal twins who had fasting hypoglycemia, hypoketonemia, muscle weakness, and hepatic dysfunction are reported. The hepatic dysfunction occurred only during periods of caloric deprivation. The surviving patient developed a cardiomyopathy. In this sibling, muscle weakness and cardiomyopathy were markedly improved by a diet high in medium chain triglycerides. There was a marked deficiency of muscle total carnitine and a mild deficiency of hepatic total carnitine. Unlike patients with systemic carnitine deficiency, serum and muscle long-chain acylcarnitine were elevated and renal reabsorption of carnitine was normal. It was postulated that the defect in long-chain fatty acid oxidation in this disorder is caused by an abnormality in the mitochondrial acylcarnitine transport.

Detailed studies of the cause of the hypoglycemia revealed that insulin, growth hormone, cortisol, and glucagon secretion were appropriate and that it is unlikely that there was a major deficiency of a glycolytic or gluconeogenic enzyme. Glucose production and alanine conversion to glucose were in the low normal range when compared to normal children in the postabsorptive state. The hypoglycemia in our patients was probably due to a modest increase in glucose consumption, secondary to the decreased oxidation of fatty acids and ketones, alternate fuels which spare glucose utilization, plus a modest decrease in hepatic glucose production secondary to decreased available hepatic energy substrates.

\section{Abbreviations}

Ala, alanine

ALT, alanine aminotransferase

AST, aspartate aminotransferase

CPK, creatine kinase

hGH, human growth hormone

LA, left atrium

LPEP/LVET, left pre-ejection period/left ventricular ejection time

$\beta$-OHB, beta-hydroxybutyrate

RPEP/RVET, right pre-ejection period/right ventricular ejection time

LVED, left ventricular end diastolic dimension

LVES, left ventricular end systolic dimension

MCT, medium chain triglyceride

$P C$, pyruvate carboxylase

PEPCK, phosphoenol phosphate carboxykinase $\mathrm{U}$, units
Hepatic long-chain acyl CoA carnitine transferase deficiency (4), multiple acyl CoA dehydrogenase deficiency (glutaric aciduria type II) (18), and systemic carnitine deficiency $(3,9,12,17,24,37$, 43), all of which are associated with impaired fatty acid oxidation, have hypoglycemia as a major clinical manifestation.

The purpose of this paper is twofold: (l) to report fraternal twins with free carnitine deficiency and long-chain acylcarnitine excess in whom hypoglycemia, hepatic dysfunction, muscle weakness, and in the surviving patient cardiomyopathy were major problems and (2) to discuss results of studies to evaluate the etiology of the disorder.

\section{CASE REPORTS}

Patient 1. The patient was the $1.8 \mathrm{-kg}$ product of $7 \frac{1}{2}$ month uncomplicated twin pregnancy. He did well until 9 months of age. After a respiratory infection (parainfluenza 3 virus recovered from nasopharynx), he developed an illness characterized by vomiting, listlessness, and hypotonia. Progressive hepatomegaly (span $6 \mathrm{~cm}$ on admission, span $12 \mathrm{~cm}, 2$ wk later) and more abnormal liver function tests (total bilirubin $2.7 \mathrm{mg} / \mathrm{dl}$, direct $1.2 \mathrm{mg} / \mathrm{dl}$, AST 90 $\mathrm{U} /$ liter, ALT $52 \mathrm{U} /$ liter, prothrombin time 14.7/13.7 $\mathrm{sec}$ on admission, total bilirubin $9.6 \mathrm{mg} / \mathrm{dl}$, direct $5.2 \mathrm{mg} / \mathrm{dl}$, AST 250 U/liter, ALT $72 \mathrm{U} /$ liter, prothrombin time 15.1/13.6 sec $2 \mathrm{wk}$ later) developed during the first 2 wk of hospitalization.

Other laboratory abnormalities included: serum $\mathrm{CO}_{2}, 12-18$ meq/liter; arterial blood pH, 7.33; blood lactate, $3700 \mu \mathrm{M}$ (normal $700-1300 \mu \mathrm{M}$ ); pyruvate, $220 \mu \mathrm{M}$ (normal 70-130 $\mu \mathrm{M}$ ); serum protein, $4.7 \mathrm{~g} / \mathrm{dl}$; albumin, $3.1 \mathrm{~g} / \mathrm{dl}$; cholesterol, $222 \mathrm{mg} / \mathrm{dl}$; and triglycerides, $242 \mathrm{mg} / \mathrm{dl}$. Serum and urine amino acids were normal. Urinary organic acids were normal when analyzed by combined gas chromatography-mass spectrometry. A percutaneous liver biopsy showed mild fibrosis and severe fatty infiltration (Fig. 1). Fasting for $11 \mathrm{~h}$ induced marked hypoglycemia (21 $\mathrm{mg} / \mathrm{dl}$ ), lactic acidosis (blood lactate, $3580 \mu \mathrm{M}$ and pyruvate 233 $\mu \mathrm{M})$, hyperuricemia $(8.1 \mathrm{mg} / \mathrm{dl})$ with appropriate serum insulin $(<4 \mu \mathrm{U} / \mathrm{ml})$, growth hormone $(56 \mathrm{ng} / \mathrm{ml})$ and plasma corticol (35 $\mu \mathrm{g} / \mathrm{dl}$ ) responses. Glucagon, $1 \mathrm{mg}$, given intramuscularly $2 \mathrm{~h}$ after a meal increased the plasma glucose from $105 \mathrm{mg} / \mathrm{dl}$ to $158 \mathrm{mg} /$ dl $30 \mathrm{~min}$ later. Fructose, $1 \mathrm{mg} / \mathrm{kg}$, given orally resulted in an equivocal late fall in the plasma glucose (to $53 \mathrm{mg} / \mathrm{dl}$ ) and a rise in plasma lactate (from 2400 to $3500 \mu \mathrm{M}$ at $60 \mathrm{~min}$ ). It was felt that fructose-1,6-diphosphatase deficiency was a diagnostic possibility. An open liver biopsy specimen was obtained to assay this enzyme. The results proved to be normal.

The patient improved slowly with a decrease in liver span to 8 


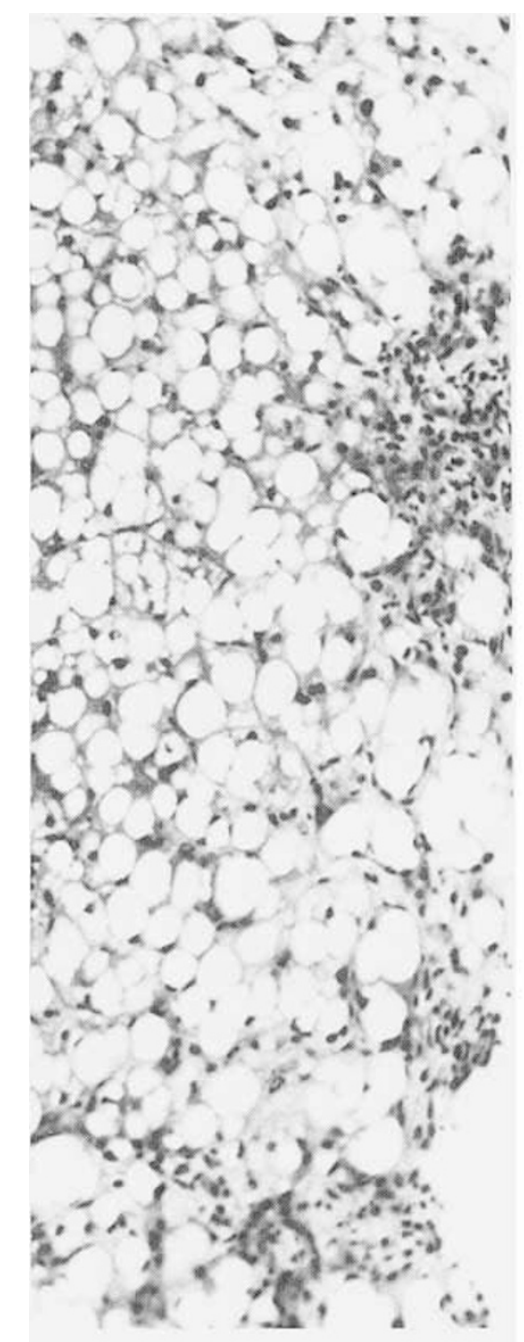

9 MONTHS

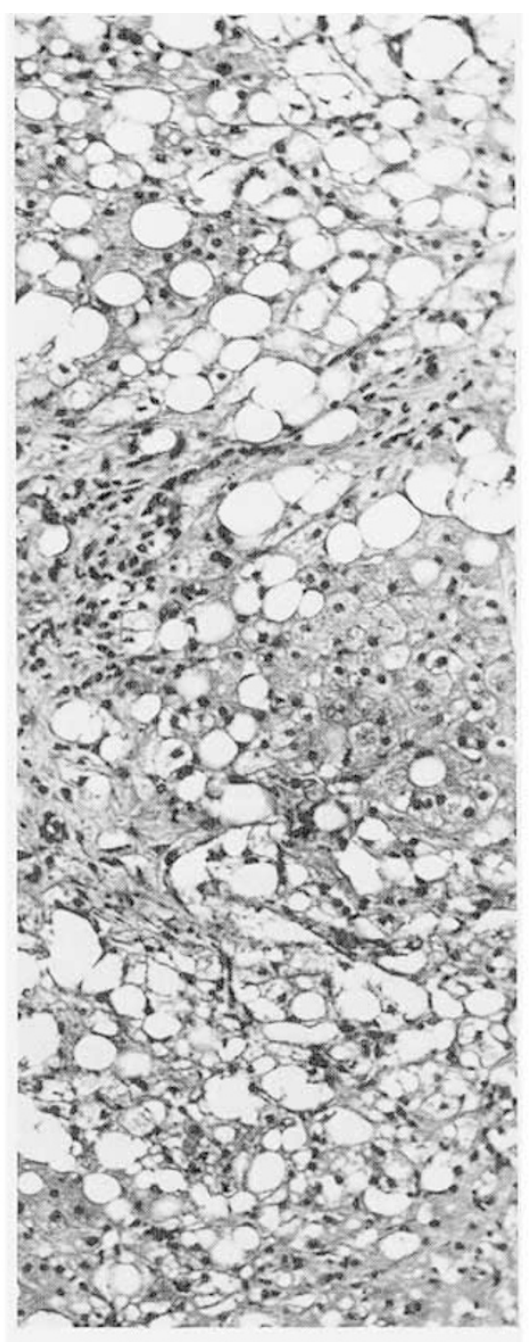

10 MONTHS

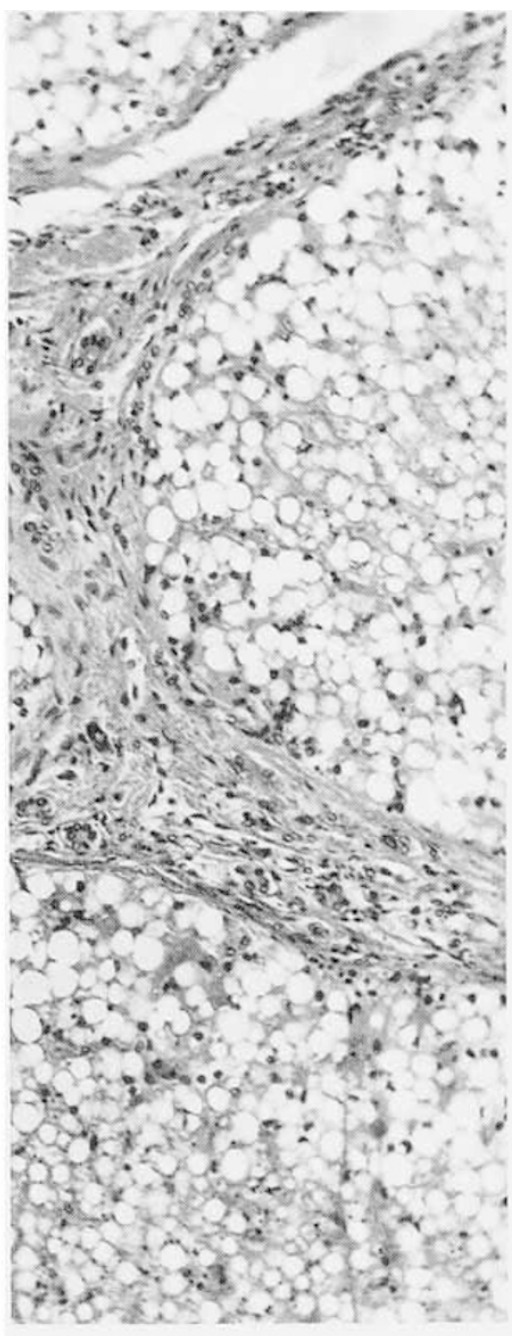

19 MONTHS

Fig. 1. Liver specimens from patient 1 at 9 months (needle biopsy), 10 months (open biopsy) and 19 months (autopsy). The enzymatic studies given in Table 4 were done on the biopsy obtained at 10 months. Hematoxin and Eosin stain, original magnification $\times 150$.

$\mathrm{cm}$, a fall in serum total bilirubin to $3.2 \mathrm{mg} / \mathrm{dl}$, and an improvement in his general demeanor but oral intake remained poor. During the seventh week of hospitalization, the patient suffered a cardiorespiratory arrest during a lumbar puncture, done for evaluation of a fever. He was resuscitated rapidly. Sepsis due to pneumococcus was documented. He spent the next 2 months in the intensive care unit with respiratory support. He had five additional episodes of sepsis due to candida albicans, pseudomonas, staphylococcus aureus, klebsiella and enterobacter. Massive ascites, intravascular coagulation, pneumonia, bilateral pneumothorax, hyperammonemia, and malnutrition were other major problems. After about 1 month, he was able to tolerate an intragastric drip of high calorie formula (Similac 24 with added polycose to make $28 \mathrm{cal} / \mathrm{oz}$ ) and slowly improved.

No infectious, toxic, or metabolic cause of his liver disease was found. After 6 months of hospitalization and 3 months of continuous feedings, the patient appeared alert and active. Growth improved markedly (Fig. 2). The serum total bilirubin was now $0.4 \mathrm{mg} / \mathrm{dl}$, the AST $67 \mathrm{U} /$ liter, and the ALT $43 \mathrm{U} /$ liter. After 8 months in the hospital, he was discharged on a program of continuous nasogastric feedings from 8 p.m. to 8 a.m. and nasogastric feedings every $4 \mathrm{~h}$ during the day. He continued to thrive. At 19 months of age, he was admitted for studies of glucose and alanine flux and for a muscle biopsy for measurement of carnitine (see below). Four days after his discharge he was readmitted having had ten watery stools, for which his nasogastric feedings had been switched to clear liquids. On admission, he was very lethargic, but irritable, with a plasma glucose of $51 \mathrm{mg} / \mathrm{dl}$. Subsequently, the plasma glucose fell to $20 \mathrm{mg} / \mathrm{dl}$ despite intravenous therapy with $10 \%$ glucose. He became unresponsive, developed marked abdominal distension and severe hepatic dysfunction (AST $1694 \mathrm{U} /$ liter, ALT $1600 \mathrm{U} /$ liter, plasma ammonia $198 \mu \mathrm{g} /$ $\mathrm{dl}($ normal, <50)). Hypotension unresponsive to therapy led to his death on the fourth hospital day.

At autopsy, the terminal ileum was necrotic and perforated. Pseudomonas difficile was cultured from a premortem blood culture. The liver (Fig. 1) showed extensive fibrosis and recent massive necrosis.

Patient 2. This patient, the fraternal twin sister of Patient 1 , suffered from transient hypoglycemia in the newborn period, but did well until she developed an upper respiratory illness and a temperature of $39.4^{\circ} \mathrm{C}$ at 9 months of age, coincident with her brother's illness. She recovered from this illness uneventfully. The AST and ALT, measured because of her brother's illness, were both greater than $600 \mathrm{U} /$ liter. They fell to 50 and $17 \mathrm{U} /$ liter, respectively, 2 wk later. Acidosis $\left(\mathrm{CO}_{2} 15 \mathrm{meq} / \mathrm{liter}\right)$, hyperuricemia $(9.9 \mathrm{mg} / \mathrm{dl})$, hypercholesterolemia $(190 \mathrm{mg} / \mathrm{dl})$, and hypertriglyceridemia $(200 \mathrm{mg} / \mathrm{dl}$ ) were variably present (most abnormal values given). Serum and urine amino acids and urinary organic acid excretion were normal. 


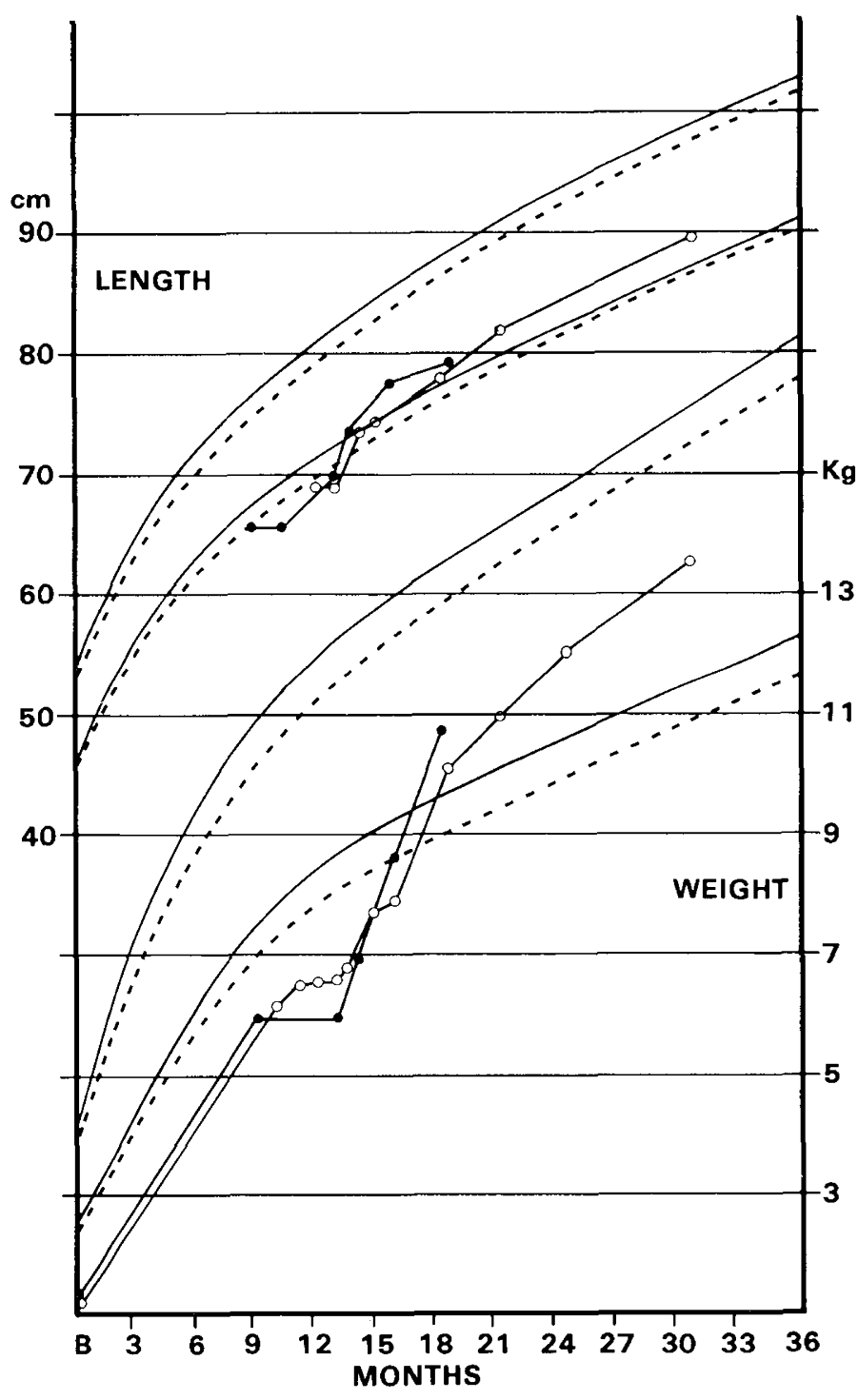

Fig. 2. Growth charts for patient 1 (closed circles) and patient 2 (open circles). The solid and dashed lines are the 5th and 95th percentiles for boys and girls, respectively. Patient $I$ was started on nasogastric feedings at 12 months of age and patient 2 at 13 months of age.

At 10 months of age, she was admitted to the hospital because of 3 days of intermittent vomiting and lethargy. Shortly after admission, the glucose was $23 \mathrm{mg} / \mathrm{dl}$, AST $335 \mathrm{U} / \mathrm{liter}$, ALT 230 $\mathrm{U} /$ liter and the total bilirubin $1.0 \mathrm{mg} / \mathrm{dl}$. She improved rapidly with intravenous glucose. She was discharged from the hospital on an every-4-h feeding schedule.

At 11 months of age, the AST was $39 \mathrm{U} /$ liter, ALT $15 \mathrm{U} /$ liter, the total bilirubin $0.2 \mathrm{mg} / \mathrm{dl}$. She was electively fasted and at $7 \mathrm{~h}$ became symptomatic with a plasma glucose of $15 \mathrm{mg} / \mathrm{dl}$.

At one year of age, she was again hospitalized because of poor feeding, irritability and occasional vomiting during a $l$-wk period. Attempts to achieve an adequate intake on a frequent feeding program failed, so she was started on a program of constant nasogastric feedings at night and intermittent nasogastric feedings during the day. On this regimen she grew well (Fig. 2) and thrived. At 19 months of age, she was rehospitalized for metabolic studies of glucose and alanine flux and for a muscle biopsy (see below).

At 21 months of age, she was started on $4 \mathrm{~g}$ D, L-carnitine per day given orally in three doses per day. After 1 month of therapy, she was hospitalized to encourage her to eat. During the preceding 10 months, while on nasogastric feedings, she had refused almost all oral intake. Her diet on admission consisted of Similac $24 \mathrm{cal} /$ oz with added polycose to make a $28 \mathrm{cal} / \mathrm{oz}$, given at $60 \mathrm{cc} / \mathrm{h}$ from 8 p.m. to 8 a.m., and $150 \mathrm{cc}$ at noon and 5 p.m. Nighttime feedings were reduced to $45 \mathrm{cc} / \mathrm{h}$ and then a week later to $30 \mathrm{cc} / \mathrm{h}$ to increase her appetite. After a further 10 days, she was eating small but inadequate amounts of food. She developed a temperature of $39^{\circ} \mathrm{C}$ and became very lethargic. The AST was now $221 \mathrm{U} /$ liter. ALT $209 \mathrm{U} /$ liter, CPK $353 \mathrm{U} /$ liter, total bilirubin $1.7 \mathrm{mg} / \mathrm{dl}$, blood glucose $111 \mathrm{mg} / \mathrm{dl}$, serum $\mathrm{CO}_{2} 13 \mathrm{meq} /$ liter, blood lactate $4167 \mu \mathrm{M}$, pyruvate $220 \mu \mathrm{M}$, plasma ammonia $101 \mu \mathrm{g} / \mathrm{dl}$. A blood culture grew $D$. pneumococcus. She recovered after therapy with antibiotics, intravenous glucose and a reinstitution of the previous dosage of the tube feedings.

At 30 months of age she had a similar episode of hepatic dysfunction associated with a gastroenteritis. She sat at 15 months of age. She walked when she was 17 months old but fell frequently. At 30 months she walked with a waddling gait and ran unsteadily. She had mild proximal muscle weakness, had difficulty climbing stairs and showed a positive Gower sign when she stood from lying.

At 36 months, she began experiencing a decreasing in exercise tolerance and occasional episodes of dyspnea. On physical examination a gallop rhythm was noted with a rate of 140 beats per $\min$.

Chest roentgenograms showed cardiomegaly. Compared with a chest film taken approximately a year earlier, the cardiothoracic ratio had increased from 0.54 to 0.58 and the left ventricle was more prominent. The electrocardiogram and Frank vectorcardiogram demonstrated left ventricular hypertrophy with strain and left atrial enlargement. M-mode echocardiogram demonstrated a dilated left ventricle (Table 1). A two-dimensional echocardiogram also demonstrated a dilated, poorly contracting left ventricle. Cardiac catheterization was performed 1 wk after initial evaluation and was compatible with a dilated cardiomyopathy with moderate mitral and tricuspid regurgitation. The left ventricular end-diastolic pressure was at upper limits of normal. The coronary arteries were normal on angiography.

The patient's nasogastric feeding was changed to Portagen to provide $88 \%$ of fat calories as medium-chain triglycerides. The previously used formula, Similac, provided $94 \%$ of fat calories as long-chain triglycerides. Total calories from fat was not changed significantly.

When re-evaluated approximately 4 wk after the dietary change, her exercise tolerance was improved and the atrial gallop was no longer present. Clinically, cardiac function was normal by 6 months after the dietary change. This was supported by a dramatic change in the echocardiographic evaluation of cardiac function (Table 2). Her skeletal muscle strength became normal. Carnitine therapy was discontinued without incident. The patient remains on high medium-chain triglyceride nasogastric feedings and is now well at 5 years of age.

\section{MATERIALS AND METHODS}

D- $\left[6,6-{ }^{2} \mathrm{H}_{2}\right]$ glucose was obtained from Merck, Sharp and Dohme, Canada Limited/Isotopes, Quebec, Canada and L-[2,3-

${ }^{13} \mathrm{C}_{2}$ ] alanine from the National Stable Isotope Resource, Los

Table 1. M-mode echocardiographic findings in patient $2^{1}$

\begin{tabular}{lccl}
\hline Age (months) & $36^{2}$ & 37 & 44 \\
LA $(\mathrm{cm})$ & 1.6 & 1.6 & 1.6 \\
LVED $(\mathrm{cm})$ & 3.8 & 3.6 & 3.4 \\
LVES $(\mathrm{cm})$ & 3.2 & 3.0 & 2.0 \\
Ejection fraction & 0.36 & 0.35 & 0.73 \\
Shortening fraction & 0.16 & 0.20 & 0.33 \\
Velocity circumferential fiber shortening & 0.8 & 0.8 & 1.5 \\
LPEP/LVET & 0.43 & 0.44 & 0.35 \\
RPEP/RVET & 0.43 & 0.30 & 0.26
\end{tabular}

'Abbreviations, see "Abbreviations."

${ }^{2}$ Before medium-chain triglyceride therapy was begun on October 10 , 1980. 
Table 2. Substrate, hormonal, and kinetic responses of both patients during the tracer infusion of $L-\left[2,3-{ }^{13} C_{2}\right]$ alanine ${ }^{1}$

\begin{tabular}{|c|c|c|c|c|c|c|c|c|c|c|c|}
\hline $\begin{array}{l}\text { Time } \\
(\mathrm{min})\end{array}$ & $\begin{array}{l}\text { Glucose } \\
(\mathrm{mg} / \mathrm{dl})\end{array}$ & $\begin{array}{c}\text { Lactate } \\
(\mu \mathrm{M})\end{array}$ & $\begin{array}{c}\text { Alanine } \\
(\mu \mathrm{M})\end{array}$ & $\begin{array}{c}\text { Glycerol } \\
(\mu \mathrm{M})\end{array}$ & $\begin{array}{c}\text { B-OHB } \\
(\mu \mathrm{M})\end{array}$ & $\begin{array}{l}\text { Insulin } \\
(\mu \mathrm{U} / \mathrm{ml})\end{array}$ & $\begin{array}{c}\mathrm{hGH} \\
(\mathrm{ng} / \mathrm{ml})\end{array}$ & $\begin{array}{l}\text { Cortisol } \\
(\mu \mathrm{g} / \mathrm{dl})\end{array}$ & $\begin{array}{c}\text { Glucagon } \\
(\mathrm{pg} / \mathrm{ml})\end{array}$ & $\begin{array}{c}\text { Glucose } \\
\text { from Ala } \\
(\%)\end{array}$ & $\begin{array}{c}\text { Alanine flux } \\
\left(\mu \text { mole } \cdot \mathrm{kg}^{-1}\right. \\
\left.\min ^{-1}\right)\end{array}$ \\
\hline \multicolumn{12}{|l|}{ Patient 1} \\
\hline 90 & 89 & 766 & 300 & 157 & 319 & & & & & 3.68 & \\
\hline 120 & 85 & 644 & 282 & 141 & 322 & & & & & 3.69 & \\
\hline 150 & 81 & 867 & 265 & 185 & 301 & & & & & 3.80 & \\
\hline 300 & 72 & 1067 & 228 & 215 & 308 & & & & & 6.23 & \\
\hline 360 & 70 & 822 & 242 & 205 & 356 & & & & & 5.81 & \\
\hline 420 & 64 & 1300 & 237 & 210 & 368 & & & & & 6.18 & \\
\hline 480 & 51 & 1844 & 302 & 104 & 363 & $<4$ & 20 & 32 & 1743 & & \\
\hline \multicolumn{12}{|l|}{ Patient 2} \\
\hline 0 & 117 & 1233 & 407 & 133 & 398 & 4 & 3 & 29 & 124 & & \\
\hline 300 & 89 & 833 & 305 & 181 & 408 & & & & & 7.39 & \\
\hline 360 & 82 & 900 & 325 & 184 & 430 & & & & & 7.14 & \\
\hline 420 & 88 & 944 & 280 & 154 & 418 & & & & & 7.67 & \\
\hline 480 & 79 & 1044 & 303 & 192 & 439 & $<4$ & 7 & 15 & 213 & 8.20 & \\
\hline
\end{tabular}

${ }^{1}$ Abbreviations, see "Abbreviations."

Alamos Scientific Laboratory, Los Alamos, NM. Each compound was tested for chemical purity by gas chromatography as several volatile derivatives on at least two gas chromatographic stationary phases of different polarity $(29,35)$.

Analytical methods. Glucose and other routine biochemical measurements were performed in the Children's Hospital clinical laboratory. Insulin, growth hormone, cortisol, and glucagon were measured by Bioscience Laboratories, Van Nuys, CA. Lactate, alanine, glycerol, and $\beta$-hydroxybutyrate were measured by specific, enzymatic microfluorometric procedures $(23,28,44,45)$. Carnitine was measured by a radiochemical technique as described by McGarry and Foster (30). Tissues homogenates and sera were prepared for assay of carnitine and carnitine esters by procedures used by Engel et al (13). $\left[{ }^{2} \mathrm{H}_{2}\right]$ and $\left[{ }^{13} \mathrm{C}\right]$ enrichment in plasma glucose and $\left[{ }^{13} \mathrm{C}\right]$ enrichment in plasma alanine were measured by computer-controlled, selected ion-monitoring gas chromatography-mass spectrometry of the acetate-boronate derivative of glucose (7) and the $N$-acetyl, $n$-propyl ester of alanine (29) as described previously.

Hepatic glycogen content and the activities of various glycogenolytic and gluconeogenic enzymes in liver and cultured fibroblasts were measured by methods indicated in Table 4.

Procedural methods. Glucose flux, as well as alanine turnover and alanine incorportation into plasma glucose were measured by the priming dose-constant intravenous infusion technique employing the non-radioactive tracers $\mathrm{D}-\left[6,6-{ }^{2} \mathrm{H}_{2}\right]$-glucose and $\mathrm{L}-\left[2,3-{ }^{13} \mathrm{C}_{2}\right]$ -alanine, respectively, according to the following protocols. Each child received his or her usual nasogastric feeding until 2 a.m. At 8 a.m., a constant infusion of $L-\left[2,3-{ }^{13} \mathrm{C}_{2}\right]$-alanine was begun at the rate of $0.046 \mu \mathrm{mole} \cdot \mathrm{kg}^{-1} \cdot \mathrm{min}^{-1}$ through a peripheral vein and continued for $8 \mathrm{~h}$. Samples for substrate content and isotopic enrichment in plasma alanine were drawn at appropriate intervals (see "Results"). After the alanine tracer infusion, the subjects each received their usual feedings until 2 a.m. the next morning. At 8 a.m. the next day, the same experimental procedure was followed except that $\mathrm{D}-\left[6,6-{ }^{2} \mathrm{H}_{2}\right]$-glucose was infused at the rate of $0.083 \mathrm{mg}$. $\mathrm{kg}^{-1} \cdot \mathrm{min}^{-1}$ after a pulse IV priming dose of $25 \mathrm{mg}$. Because plasma alanine content and isotopic enrichment remained constant during the final $6 \mathrm{~h}$ of the infusion study, alanine flux was calculated by conventional steady state expressions (17). Because plasma glucose fell during the second study, glucose inflow to (production) and efflux from (utilization) the plasma compartment were calculated by the non-steady state approximations of Steele (41) using a mixing volume of $65 \%$ of the glucose pool size (extracellular space) $(10)$. The $\%$ glucose from alanine was calculated by standard precursor-product relationships (7). Because the true precursor isotope enrichment is found in the hepatocyte and not in the peripheral pool sampled in the present work and because randomization of label in the Krebs cycle will cause underestimation of the actual net rate of glucose synthesis from alanine (27), the reported \% contributions of alanine carbon to glucose carbon in the present study must be viewed as reasonable estimates only.

The renal tubular reabsorption rates, reabsorptive maxima, and apparent renal plasma excretory threshold for carnitine were determined as previously described (13).

\section{RESULTS}

Both children were fasted on several occasions. The results of all the studies are not presented because they are quantitatively and qualitatively similar to the results of the isotope studies discussed below. On each occasion fasting caused symptomatic hypoglycemia within 10-14 h. Both children were able to tolerate a 14- $h$ fast the day of the alanine infusion (Table 2) but became hypoglycemic the next day during a second 14-hour fast (Table 3).

When the subjects were normoglycemic, plasma insulin, cortisol, growth hormone, and glucagon values were normal; when hypoglycemic, there were appropriate cortisol, growth hormone, and glucagon elevations (Tables 2 and 3). Prior plasma lactate and pyruvate levels were measured numerous times (cf. case reports) often found elevated, on occasion, rose further during a fast. But normal lactate values (20) were observed during the alanine tracer study (Table 2) and only mildly elevated levels (20) were seen during the course of the dideuteroglucose infusion (Table 3 ). Plasma alanine and glycerol remained normal in both subjects throughout the 13-14 h fasting period of each experimental protocol (Table 2 and 3$)(20,34,38,40)$. The gradual rise in glycerol particularly during the second study indicates active lipolysis. Plasma $\beta$-hydroxybutyrate was also within normal limits $(20,34$, 38,40 ) when the children were normoglycemic but remained 
Table 3. Substrate, hormonal, and kinetic responses of both patients during the tracer infusion of $\mathrm{D}-\left[6,6-{ }^{2} \mathrm{H}_{2}\right] \mathrm{glucose} \mathrm{C}^{1}$

\begin{tabular}{|c|c|c|c|c|c|c|c|c|c|c|c|}
\hline $\begin{array}{l}\text { Time } \\
(\min )\end{array}$ & $\begin{array}{l}\text { Glucose } \\
(\mathrm{mg} / \mathrm{dl})\end{array}$ & $\begin{array}{c}\text { Lactate } \\
(\mu \mathrm{M})\end{array}$ & $\begin{array}{c}\text { Alanine } \\
(\mu \mathrm{M})\end{array}$ & $\begin{array}{c}\text { Glycerol } \\
(\mu \mathrm{M})\end{array}$ & $\begin{array}{c}\beta-\mathrm{OHB} \\
(\mu \mathrm{M})\end{array}$ & $\begin{array}{c}\text { Insulin } \\
(\mu \mathrm{U} / \mathrm{ml})\end{array}$ & $\begin{array}{c}\mathrm{hGH} \\
(\mathrm{ng} / \mathrm{ml})\end{array}$ & $\begin{array}{l}\text { Cortisol } \\
(\mu \mathrm{g} / \mathrm{dl})\end{array}$ & $\begin{array}{l}\text { Glucagon } \\
(\mathrm{pg} / \mathrm{ml})\end{array}$ & $\begin{array}{l}\text { Glucose in- } \\
\text { flow } \\
\text { (mg.k }\end{array}$ & $\begin{array}{l}\text { Glucose outflow } \\
\left.\mathrm{kg}^{-1} \cdot \mathrm{min}^{-1}\right)\end{array}$ \\
\hline \multicolumn{12}{|l|}{ Patient 1} \\
\hline 80 & 86 & 1533 & 263 & 340 & 279 & & & & & 7.75 & 7.10 \\
\hline 130 & 104 & 1188 & 258 & 333 & 273 & & & & & 7.97 & 8.56 \\
\hline 200 & 81 & 1866 & 321 & 413 & 307 & $<4$ & 21 & 30 & 708 & 7.27 & 7.36 \\
\hline 360 & 61 & 2122 & 351 & 420 & 321 & & & & & 5.21 & 5.83 \\
\hline 450 & 30 & 2433 & 359 & 345 & 365 & $<4$ & 15 & 58 & 4820 & & \\
\hline \multicolumn{12}{|l|}{ Patient 2} \\
\hline 0 & 100 & 1911 & 378 & 348 & 319 & 5 & 19 & 39 & 199 & & \\
\hline 70 & 74 & 2089 & 303 & 397 & 356 & & & & & 7.57 & 7.60 \\
\hline 130 & 73 & 1356 & 301 & 349 & 355 & & & & & 6.76 & 7.34 \\
\hline
\end{tabular}

'Abbreviations, see "Abbreviations."

essentially unchanged when the subjects became hypoglycemic; thus, there was an inappropriate hypoketonemia for the level of glycemia (20-34).

During the final $6-\mathrm{h}$ steady state period of the $\mathrm{L}-\left[2,3-{ }^{13} \mathrm{C}_{2}\right]-$ alanine tracer study, corresponding to $8-14 \mathrm{~h}$ of fasting, alanine flux averaged $8.5 \mathrm{~mole} \cdot \mathrm{kg}^{-1} \cdot \mathrm{min}^{-1}$ in patient 1 and $10.7 \mathrm{~mole}$. $\mathrm{kg}^{-1} \cdot \mathrm{min}^{-1}$ in patient 2 . Both values are within the normal range $(19,21)$. The $\%$ glucose from alanine continued to rise for the first $4-5 \mathrm{~h}$ of study but then approached plateau values averaging 6.2 and $7.5 \%$ in subjects 1 and 2, respectively (Table 3). There are virtually no normal control values for alanine contribution to glucose in childhood but the above values are in the range found in normal newborns studied with $L-\left[2,3-{ }^{13} \mathrm{C}_{2}\right]$-alanine $(16)$ and in adults with radiolabeled alanine (10).

During the course of the dideuteroglucose tracer study, both subjects showed progressively falling plasma glucose levels, both became symptomatic. In both patients, glucose production was initially in the normal range (8) but fell to below normal over the course of the study. Hypoglycemia developed because glucose utilization exceeded production by $4.2 \mathrm{mg} / \mathrm{min}$ for the final 270 min of observation in patient 2 .

The results of the assays of hepatic and fibroblast enzyme activity and of hepatic glycogen are given in Table 4 . The activity of all the enzymes assayed in the liver biopsy specimen from patient 1 were moderately low. Because enzyme activity was measured relative to total net weight of liver, the generalized reductions observed presumably are secondary to the increased hepatic content of fibrous tissue and triglyceride with resultant decrease in actual hepatocyte mass.

Most of the enzyme activities were approximately two-thirds the lower limit of normal; however, PEPCK activity seemed to be reduced somewhat out of proportion being only about $25 \%$ of a simultaneous control. PEPCK activity was normal in fibroblasts. The enzyme in fibroblasts is probably the mitochondrial isozyme (2).

Total muscle carnitine levels were markedly reduced in both twins but despite this decrease the muscle long-chain acylcarnitine contents were four times higher than the highest control value (Table 5). Liver carnitine was significantly reduced in Patient 1 , but this may, in part, reflect generalized liver damage. The longchain acylcarnitine level in this patient's liver, however, was higher than normal. Liver carnitine levels were only slightly reduced in
Table 4. Enzymes of glucose and glycogen metabolism and hepatic glycogen in biopsy specimens taken from the livers of patient 1

\begin{tabular}{|c|c|c|c|}
\hline Enzyme & Activity & $\begin{array}{c}\text { Normal } \\
\left(\mu \mathrm{mole} \cdot \mathrm{min}^{-1}\right. \\
\left.\mathrm{g}^{-1}\right)\end{array}$ & Assay by \\
\hline \multicolumn{4}{|l|}{ Liver $^{1}$} \\
\hline $\begin{array}{l}\text { Fructose-1, } 6 \text { diphos- } \\
\text { phate }\end{array}$ & 1.8 & $3-8^{2}$ & Ref. 31 \\
\hline Phosphorylase & 8.7 & $15-30$ & Ref. 5 \\
\hline Debranching enzyme & 0.18 & $0.2-0.6$ & Ref. 5 \\
\hline Acid a glucosidase & 0.88 & $0.7-2.0$ & Ref. 6 \\
\hline Aldolase & 2.0 & $3-12$ & Ref. 31 \\
\hline Glucose 6 phosphatase & 4.8 & $4-10$ & Ref. 5 \\
\hline Pyruvate carboxylase & 5.8 & $8.6(6-12)^{3}$ & Ref. 1 \\
\hline $\begin{array}{l}\text { Phosphoenolpyruvate } \\
\text { carboxykinase }\end{array}$ & 2.7 & $10.4(5-11)^{3}$ & Ref. 1 \\
\hline $\begin{array}{l}\text { Carnitine palmityl trans- } \\
\text { ferase }^{4}\end{array}$ & 0.27 & $0.1-0.24^{2}$ & Ref. 42 \\
\hline Glycogen content & \multicolumn{2}{|c|}{$3.2 \mathrm{~g} / 100 \mathrm{~g}$ wet weight } & \\
\hline Fibroblasts & & $\begin{array}{l}\text { Patient }(\mathrm{mU} / \mathrm{mg} \\
\text { protein) }\end{array}$ & $\begin{array}{c}\text { Control } \\
\text { (mU/mg } \\
\text { protein) }\end{array}$ \\
\hline \multicolumn{4}{|l|}{ Enzyme } \\
\hline Pyruvate carboxylase & & 1.95 & 1.35 \\
\hline $\begin{array}{l}\text { Phosphoenolpyruvate } \\
\text { nase }^{5}\end{array}$ & carboxyki- & 1.61 & 1.84 \\
\hline \multicolumn{4}{|c|}{ Pyruvate dehydrogenase complex } \\
\hline \multicolumn{4}{|c|}{ Treatment } \\
\hline None & & 0.31 & 0.41 \\
\hline Activated & & 5.85 & 4.7 \\
\hline Inactivated & & 0.00 & 0.04 \\
\hline
\end{tabular}

' Open liver biopsy specimen obtained at 10 months of age. Histology showed moderately severe fibrosis and fatty infiltration (see text and Fig. 1). The biopsy was obtained after an 8 -h fast during which time the patient received intravenous glucose.

${ }^{2}$ Normal range.

${ }^{3}$ Simultaneous control (normal range).

${ }^{4}$ Autopsy specimen.

${ }^{5}$ The phosphoenolpyruvate carboxykinase in fibroblasts appears to be entirely the mitochondrial isozyme. 
Table 5. Serum and Tissue Carnitine Levels ${ }^{1}$

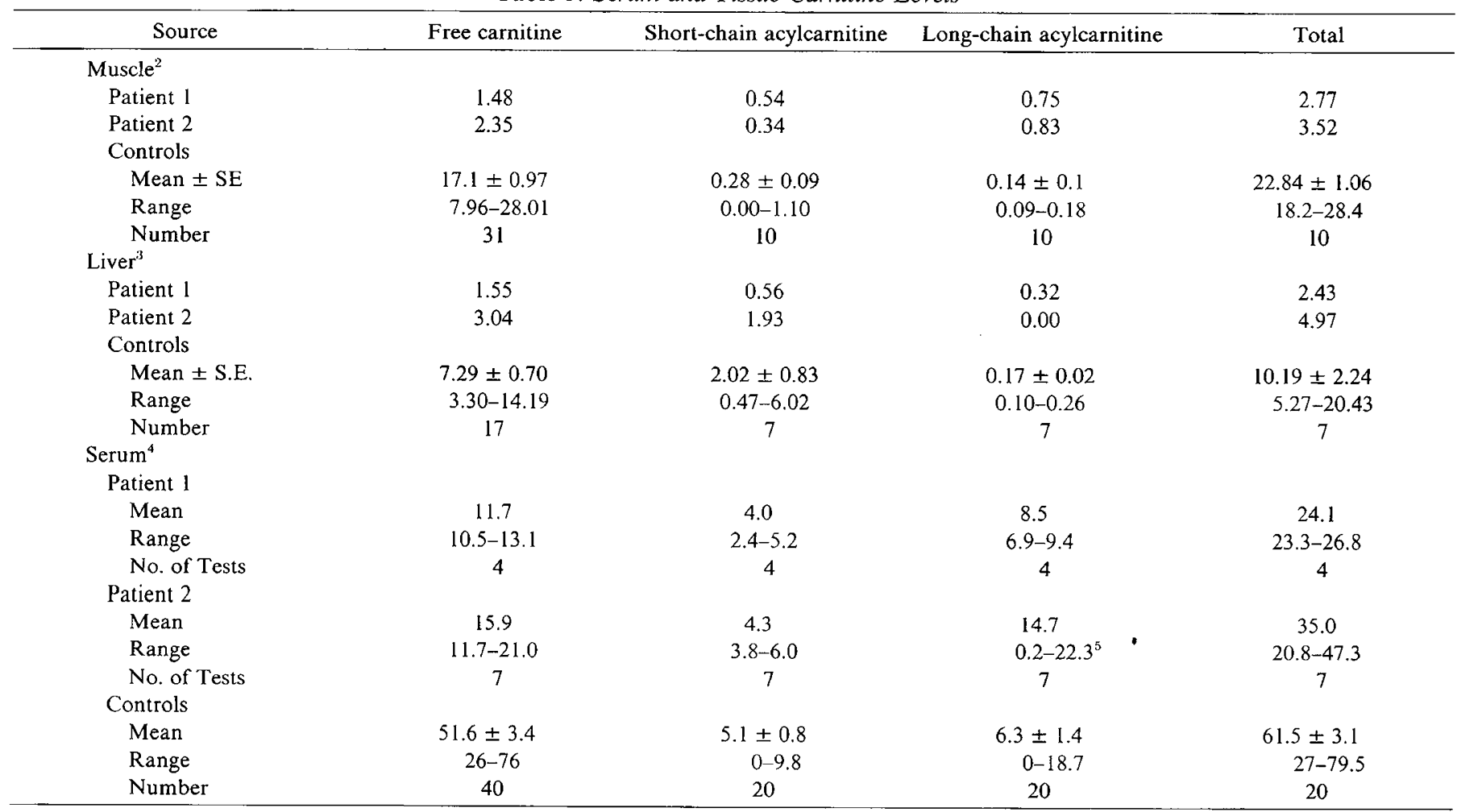

${ }_{1}^{1}$ Tissue carnitine levels are expressed in nmole/mg noncollagen protein, serum carnitine levels indicate $\mathrm{nmole} / \mathrm{ml}$.

${ }^{2}$ Muscle biopsies were obtained at 19 months.

${ }^{3}$ Liver biopsy from patient 2 was obtained at 20 months. Histology of this specimen was normal. Liver specimen from patient 1 was obtained at autopsy.

${ }^{4}$ Serum samples from patient 1 were obtained at 10 and 19 months and from patient 2 at 10,19 , and 30 months.

${ }^{5}$ Lowest value of $0.2 \mathrm{nmole} / \mathrm{ml}$ was obtained at 10 months. Subsequent values ranged $11.5-22.3 \mathrm{nmole} / \mathrm{ml}$.

${ }^{4}$ Serum samples from patient 1 were obtained at 10 and 19 months and from patient 2 at 10,19 , and 30 months

sowest value of $0.2 \mathrm{nmole} / \mathrm{ml}$ was obtained at 10 months. Subsequent values ranged $11.5-22.3 \mathrm{nmole} / \mathrm{ml}$.

Patient 2. Free serum carnitine levels fluctuated but were generally depres̀sed. Despite this decrease, the mean serum long-chain acylcarnitine values were higher than the normal mean value. Long-chain acyl CoA carnitine transferase activities, determined in liver in Patient 1 (Table 4) and in muscle in Patient 2 were normal.

The renal handling of carnitine was studied in Patient 2 at age 30 months. For both free and total carnitine, the apparent renal excretory threshold, the renal tubular reabsorptive maximum and the tubular reabsorption rate at plasma levels of $60 \mathrm{nmole} / \mathrm{ml}$ for free carnitine and $65 \mathrm{nmole} / \mathrm{ml}$ for total carnitine, were in the normal range.

During the renal function test the patient received $\mathrm{L}$-carnitine intravenously at a constant rate of $0.25 \mathrm{nmole} / \mathrm{min} / \mathrm{kg}$ for 200 min and serum levels of free carnitine, short-chain acylcarnitine and long-chain acylcarnitine were monitored at 30-min intervals. The serum long-chain acylcarnitine levels $(\mathrm{nmole} / \mathrm{ml}$ ) in the patient were higher before and during the infusion than in nine normal controls or in four patients with systemic carnitine deficiency. For the patient, this value was 15.2 before the infusion and rose to a maximum of 34.7 during the infusion. The mean value during the infusion was 22.8 . In the other subjects the preinfusion long-chain acylcarinitine values ranged from $0-4.2$. During the infusion, these values fluctuated irregularly or rose slightly. The mean values during infusion in the controls ranged from $0-10.6$ and in the patients with systemic carnitine deficiency from 1.2 to 5.7 .

\section{DISCUSSION}

The deleterious effects of fasting, the hypoketonemia and the beneficial effect of medium-chain triglycerides indicate that our patients have a defect of long-chain fatty acid oxidation.

The illness resembles primary systemic carnitine deficiency in the following: intermittent episodes of metabolic encephalopathy associated with hypoglycemia, and low muscle and serum carnitine levels. But the twins differ in several respects from other patients with primary systemic carnitine deficiency described previously $(6,14)$. (1) Patient 1 had cyclic and marked elevations of bilirubin on caloric deprivation or during spontaneous attacks of metabolic encephalopathy. He also had severe anorexia, recurrent infections, and developed postnecrotic cirrhosis. Although he had low liver carnitine levels, this could be readily explained by cachexia and severe hepatocellular injury (36). (2) The liver carnitine level in Patient 2 was only slightly below the lower normal level and it is difficult to explain how such a slight decrease could result in severe impairment of fatty acid oxidation. (3) Patient 2 had no renal carnitine leak whereas four previously investigated patients with primary systemic carnitine deficiency did show such a leak. (4) Despite the low free and total muscle carnitine level, the long-chain acylcarnitine levels in patients were higher than normal in muscle and relatively high, and at times higher than normal, in serum. Further, in Patient 2, infusion of free carnitine resulted in an additional increase of the serum longchain acylcarnitine level.

A possible explanation of the findings would be a block in the mitochondrial transport of long-chain acylcarnitines. This transport depends on a carnitine-acylcarnitine translocase system (32, 33). Such a block would clearly inhibit the oxidation of long-chain fatty acids and could account for the high acylcarnitine levels. Because this system is not necessary for the oxidation of MCT such a defect would account for the beneficial effect of MCT therapy. The low muscle levels of free carnitine might be explained if a block in mitochondrial acylcarnitine transport inhibited cellular carnitine uptake. Direct assays of the translocase system will be required to substantiate this hypothesis.

The features of hepatic dysfunction in our patients have de- 
pended on the duration and severity of caloric deprivation. Acute total fasting caused symptomatic hypoglycemia usually without other evidence of hepatic dysfunction. After somewhat longer but less severe caloric deprivation, lethargy, hepatomegaly, elevated serum transaminases and mild hyperbilirubinemia $(1-2 \mathrm{mg} / \mathrm{dl})$ were observed. Hypoglycemia was not observed as long as a marginal caloric intake was maintained.

All of the episodes of sepsis in our patients occurred after periods of inadequate caloric intake, and most episodes in Patient 1 developed when he was severely debilitated and was supported by central venous lines and intubation. A predisposition for sepsis has been noted in patients who are ill with other metabolic disorders $(11,35)$ but has never been observed in primary systemic carnitine deficiency.

One clear goal of therapy in similar patients should be to avoid prolonged fasting. During intercurrent illnesses, a special effort should be made to maintain a high caloric intake. Our patient's muscle and cardiac function improved markedly after most of her fat calories were switched to medium-chain triglycerides. Mediumchain triglycerides may be of benefit in patients with systemic carnitine deficiency and other defects that impair long chain fatty acid oxidation.

Glucose homeostasis was studied in detail in our patients. Insulin, growth hormone, glucagon, and cortisol levels were appropriate; thus, the hypoglycemia does not appear to be due to a regulatory abnormality in the major glucoregulatory hormones.

The interpretation of enzyme activities in liver in Patient 1 is made difficult by the generalized liver damage and the fatty change. The available studies are sufficient to exclude major impairment of key glycolytic or gluconeogenic enzymes with the exception of PEPCK for which the available studies are less clear cut. Total hepatic PEPCK was $25 \%$ of a simultaneously run control. Assuming that the reduction in the PC, which was measured at the same time, was due to the generalized liver disease and that the generalized disease would reduce all enzymes proportionally, the PEPCK can be corrected to $38 \%$ normal (\% normal PEPCK divided by \% normal PC).

We view this value as intermediate, not particularly suggestive of a limiting isolated deficiency of this enzyme, but not eliminating the possibility, particularly in this case where there are two isozymes. For example, the $38 \%$ normal activity would be consistent with two normally equally active isozymes, one absent, the other nearly normal. But the apparently normal incorporation of $\left[{ }^{13} \mathrm{C}\right]$ alanine carbon into glucose is strong evidence against a major PEPCK deficiency.

Glucose production rates $8-14 \mathrm{~h}$ after the last meal were low to normal compared with non-hypoglycemic postabsorptive children (8). Glucose utilization, however, was consistently higher than production as indicated by the falling blood glucose in both children. Although this difference between production and consumption only amounted to $40 \mathrm{mg} / \mathrm{min}$ on the average, a small difference can account for the fall in plasma glucose from approximately $70-80 \mathrm{mg} / \mathrm{dl}$ to $15-30 \mathrm{mg} / \mathrm{dl}$ in $10 \mathrm{~kg}$ children such as these over a $4-4.5-h$ period. Glucose flux is reduced when the blood sugar is lowered by longer fasting in children $(22,25,26)$. Total energy utilization does not diminish as a result of fasting but the energy source shifts from oxidation of carbohydrate to that of fat $(38,39)$. Glucose flux correlates inversely with the degree of ketonemia, suggesting a sparing effect on cerebral glucose consumption (25).

In our patients, the presence of inappropriate hypoketonemia and a persistently greater glucose utilization compared with hepatic glucose production in the face of low plasma glucose suggests that hypoglycemia may in part result from a decreased availability of alternate fuel sources because fatty acid oxidation (and consequently ketogenesis) was impaired. Appropriate hepatic glucose output responses in children who become hypoglycemic after 8$14 \mathrm{~h}$ of food deprivation are unknown. One would anticipate an increase in glucose production to compensate for a falling plasma glucose however, as our patients become hypoglycemic glucose production decreased. This may indicate a function impairment of gluconeogenesis.
REFERENCES AND NOTES

I. Atkin, B. M., Neil, R. M., Utter, M. F., Leiter, A. B., and Banker, B. Q.: Pyruvate carboxylase deficiency and lactic acidosis in a retarded child without Leigh's Disease. Pediatr. Res., 13: 109 (1979).

2. Atkin, B. M., Utter, M. F., and Weinberg, M. B.: Pyruvate carboxylase and phosphoenol pyruvate carboxykinase activity in leukocytes and fibroblasts from a patient with pyruvate carboxylase deficiency. Pediatr. Res., 13: 38 (1979).

3. Boudin, G., Mikol, J., Guillard, A., and Engel, A. G.: Fatal systemic carnitine deficiency with lipid storage in skeletal muscle, heart, liver and kidney. $\mathbf{J}$. Neurol. Sci. 30: 313, 1976.

4. Boughneres, P. F., Saudubray, J. M., Marsac, C., Bernard, O., Odievre, M., and Girard, J. R.: Deceased Ketogenesis due to deficiency of hepatic carnitine acyl transferase. N. Engl. J. Med., 302: 123 (1980).

5. Brown, B. I. and Brown, D. H.: Glucose-6-phosphatase, debranching enzyme and phosphorylase: "Glycogen Storage Diseases." in Carbohydrate Metabolism and Its Disorders, Vol. II, Ed. by Dickens, Randle and Wheland, (Academic Press, New York 1968)

6. Brown, B. I., Brown, D. H., and Jeffrey, P. L.: Acid a-glucosidase: Simultaneous Absence of a-1, 4-Glucosidase and a-1, 6-Glucosidase Activities (pH 4) in Tissues of Children with Type II Glycogen Storage Disease. Biochemistry, 9: 1423 (1970).

7. Bier, D. M., Arnold, K. J., Sherman, W. R., Holland, W. H., Holmes, W. F., and Kipnis, D. M.: In-vivo measurement of glucose and alanine metabolism with stable isotopic tracers. Diabetes, 21: 1005 (1977).

8. Bier, D. M., Leake, R. D., Haymond, M. W., Arnold, K. J., Gruenke, L. D., Sperling, M. A., and Kipnis, D. M.: Measurement of true glucose production rates in infancy and childhood with 6,6 Dideutero glucose. Diabetes, 26: 1016 (1977).

9. Cornelio, F., DiDonato, S., Peluchetti, D., Bizzi, A., Bertagnolio, B., D’Angelo, A., and Wiesmann, U.: Fatal cases of lipid storage myopathy with carnitine deficiency: Morphological and metabolic correlations in two cases. Can. J. Neurol. Sci., S: 205, 213 (1978).

10. Cowan, J. S. and Hetanyi, F. Jr.: Glucoregulatory responses in normal and diabetic dogs recorded by a new tracer method. Metabolism, 20: 360 (1971)

11. Dancis, J., and Levitz, M.: Abnormalities of branched-chain amino acid metabolism. The Metabolic Basis of Inherited Disease. 3d ed. Stanbury JB, Wyngaarden JB, and Fredrickson DS (Eds.) Chapter 21. (McGraw Hill, New York, 1972)

12. Engel, A. G., Banker, B. Q., and Eiben, R. M.: Carnitine deficiency: Clinical, morphological and biochemical observations in a fatal case. J. Neurol. Neurosurg. Psychiatry 40: 313 (1977).

13. Engel, A. G., Rebouche, C. J., Wilson, D. M., Glasgow, A. M., Romshe, C. A., and Cruse, R. P.: Primary sustemic carnitine deficiency. 11. Renal handling of carnitine. Neurology (NY) 31: 819 (1981).

14. Engel, A. G.: Possible causes and effects of carnitine deficiency in man. In: Carnitine Biosynthesis, Metabolism, and Functions, Frenkel, RA and McGarry, D. Eds., pp 271-284 (Academic Press, N.Y., 1980).

15. Felig, P.: The Glucose-Alanine Cycle. Metabolism, 22: 179 (1973).

16. Frazer, T. E., Karl, I. E., Hillman, L. S., and Bier, D. M.: Direct measurement of gluconeogenesis from $\left[2,3-{ }^{13} \mathrm{C},\right]$ alanine in the human neonate during the first 8 hours of life. Am. J. Physio., 240: E615 (1981).

17. Glasgow, A. M., Eng, G., and Engel, A. G.: Systemic carnitine deficiency simulating recurrent Reye's syndrome. J. Pediatr., 96: 889 (1980).

18. Goodman, S. I., McCabe, E. R. B., Fennessey, P. V., and Mace, J. W.: Multiple acyl-CoA dehydrogenase deficiency (glutaric aciduria type II) with transient hypersarcosinemia and sarcosinuria; possible inherited deficiency of an electron transfer flavoprotein. Pediatr. Res., 14: 12 (1980)

19. Haymond, M. W., Ben-Galim, E., and Strobel, K. E.: Glucose and alanine metabolism in children with maple syrup urine disease. J. Clin. Invest., 63: 398 (1979).

20. Haymond, M. W., Karl, I., Weldon, V. V., and Pagliara, A. S.: The role of growth hormone and cortisone in glucose and gluconeogenic substrate regulation in fasted hypopituitary children. J. Clin. Endocrinol. Metab., 42: 846 (1979).

21. Haymond, M. W., Strauss, A. W., Arnold, K. J., and Bier, D. M.: Glucose homeostasis in children with severe cyanotic congenital heart disease. J. Pediatr., 95: 220 (1979).

22. Haymond, M., Strobel, K., Ben-Galim, E., and DeVivo, D.: Effect of ketosis on glucose and alanine fluxes in children. Clin. Res., 26: 682abstract (1978).

23. Karl, 1. E., A. Pagliara, A., and Kipnis, D. M.: A microfluorometric enzymatic assay for determination of alanine and pyruvate in plasma and tissues. J. Lab. Clin. Med., 804: 834 (1972).

24. Karpati, G., Carpenter, S., Engel, A. G., Watters, G., Alan J., Rothman S., Klassen, G., and Mamer, O. A.: The syndrome of systemic carnitine deficiency. Clinical, morphologic biochemical and pathophysiologic features. Neurology (Minneap), 25: 16 (1975).

25. Kerr, D. S., Stevens, M. C. G., and Picou, D. I. M., Fasting metabolism in infants: II. The effect of severe undernutrition and infusion of alanine on glucose production estimated with $\mathrm{U}^{-{ }^{13} \mathrm{C}} \mathrm{C}$-glucose. Metabolism, 27: 831 (1978).

26. Kerr, D. S., M. C. G. Stevens, and H. M. Robinson, Fasting metabolism in infants: I. The effect of severe undernutrition on energy and protein utilization. Metabolism, 27: 411 (1978).

27. Krebs, H. A., Hems, R., Weidmann, M. J., and Speake, R. N.: The fate of isotopic carbon in kidney cortex synthesizing glucose. Biochem. J., 101: 242 (1966).

28. Lowry, O. H. and Passoneau, J. V.: A flexible system of enzymatic analysis, p. 200. (Academic Press, New York, 1972).

29. Matthews, D. E., Ben-Galim, E., and Bier, D. M.: Determination of stable 
isotopic enrichment in individual plasma amino acids by chemical ionization mass spectrometry. Anal. Chem., 51: 80 (1979).

30. McGarry, J. D. and Foster, D. W.: An improved and simplified radioisotopic assay for the determination of free and esterified carnitine. J. Lipid Res., I7: 277 (1976).

31. Paglara, A. S., Karl, I. E., Keating, J. P., Brown, B. I., and Kipnis, D. M.: Aldolase and fructose diphosphatase: "Hepatic Fructose-1, 6-Diphosphatase Deficiency." J. Clin. Invest., 51: 2115 (1972).

32. Pande, S. V.: A mitochondrial carnitine acylcarnitine translocase system. Proc. Natl. Acad. Sci. USA, 72: 883 (1975).

33. Pande, S. V., Parvin, R.: Carnitine-acylcarnitine translocase catalyzes an equilibrating unidirectional transport as well. J. Biol. Chem., 255: 2994 (1980).

34. Persson, B. and Gentz, J., The Pattern of Blood Lipids, Glycerol and Ketone Bodies during the Neonatal Period, Infancy and Childhood. Acta. Pediatr. Scand., 55: 353 (1966).

35. Rosenberg, L. E.: Disorders of propionate methylmalonate and Vitamin $B_{12}$ metabolism in the metabolic basis of inherited disease. 3d. ed. Stanbury JB, Wyngaarden JB, and Frederickson DS (Eds). Chapter 22. (McGraw Hill, New York, 1972).

36. Rudman, D., Sewell, C. W., Ansley, J. D.: Deficiency of carnitine in cachectic cirrhotic patients. J. Clin. Invest., 60: 716 (1977).

37. Scarlato, G., Pellegrini, G., Cerri, C., Meola, G., and Veicsteinas, A.: The syndrome of carnitine deficiency: Morphological and metabolic correlations in two cases. Can. J. Neurol. Sci., 5: 205 (1978).

38. Senior, B., and Loridan, L.: Gluconeogenesis and insulin in the ketotic variety of childhood hypoglycemia and in control children J. Pediatr., 74: 529 (1969).

39. Shipley, R. A., and Clark, R. E.: Tracer Methods for In Vivo Kinetics. p. 146. (Academic Press, New York, 1972).

40. Stanley, D. A., and Baker, L.: Hyperinsulinism in Infancy: Diagnosis by Demonstration of Abnormal Response to Fasting Hypoglycemia. Pediatrics, 57: 702 (1976).

41. Steele, R.: Influences of glucose loading and of injected insulin in hepatic glucose output. Ann. N.Y. Acad. Sci., 82: 420 (1959).

42. Van Tol A. and Hulsmann, W. C.: The localization of palmitoyl-CoA:carnitine transferase in rat liver. Biochim. Biophys. Acta, 189: 342 (1969).

43. Ware, A. J., Burton, W. C., McGarry, J. D., Marks, J. F., and Weinberg, A. G.: Systemic carnitine deficiency. Report of a fatal case with multisystemic manifestations. J. Pediatr., 93: 959 (1978).

44. Wieland, O.: In Methods of Enzymatic Analysis, Bergmeyer, H.U. (Ed.). p. 1404. (Academic Press, New York 1974).

45. Williamson, D. H. and Mellanby, J.: Methods of Enzymatic Analysis. Ed.: H. U. Bergmeyer. p. 1836 (Academic Press, New York 1974).

46. Requests for reprints should be addressed to: Dr. Allen M. Glasgow, Departments of Endocrinology and Metabolism, Children's Hospital National Medical Center, 111 Michigan Ave. N.W., Washington, D.C. 20010.

47. This work was supported in part by NIH grants HD-10667 and RR 00954 (DMB), NIH grant NS 6277 and a research center grant from the Muscular Dystrophy Association (AGE), NIH grants GM 04761 and HD 12184 (BIB)

48. Received for publication February 24, 1982.

49. Accepted for publication October 1, 1982. 